\title{
Introduction: Being Global, Regional, and Local in the Asia Pacific
}

\author{
Ho Khai Leong \\ Visiting Professor, Department of International Affairs, Wenzao Ursuline \\ University of Languages, Kaohsiung, Taiwan \\ ho_khai_leong@hotmail.com
}

On the surface, political and socio-economic issues at the local, regional and global levels appear to be discrete and have little bearing on one another. However, the notion that local matters pertain only to a certain area within a specific country, regional matters only concern a particular geographical area such as Europe or Asia, and global matters are international ones that concern all parts of the world is overly simplistic. All issues, be they local, regional or global do not occur in isolation, for global matters can trickle down to shape local issues in areas in all countries and local issues of countries can grow in severity to eventually impact international affairs. Although it is true that each country has its own local interests and concerns; it is also part of its immediate region and is dependent on its immediate neighbors for trade and labor; the inhabitants of each nation are also part of the world as global citizens due to exposure to and absorption of other cultures and ideologies. Each country is affected by local, regional and global events. After all, we have had numerous instances of global issues such as economic recessions, international conflicts and the 2020 novel coronavirus pandemic affecting the everyday lives of all the citizens of the world. As John Donne presciently notes in his Devotions Upon Emergent Occasions, Meditation XVII, written in 1623:

"No man is an island entire of itself; every man is a piece of the continent, a part of the main..."

Now, more than ever, no matter how inward looking a country or its leaders might be, the near ubiquitous access to the internet, the proliferation of mobile phone applications like WhatsApp and the easy availability of commercial flights all over the world prevent any nation from being truly isolationist, however much they believe they stand apart from other countries. This issue of 
Bandung recognizes and celebrates the interconnectedness between the local, regional and global. It would be as erroneous to dismiss global issues like climate change as secondary to regional matters like trade in Southeast Asia, just as it would be folly to suppose that global issues have no bearing on local ones or vice versa. Although the papers in this volume are mostly Asia Pacificcentric, they acknowledge that all local, regional and global matters are "part of the main" and that no area or issue is "an island entire of itself". As will be seen herein, the countries of Southeast Asia and its neighbors are caught in the middle of being local, regional and global at the same time. To better illustrate this, let us consider the contributions to this compilation and the multifarious ways in which the global has impacted the regional, and how both the global and regional have affected particular local issues.

\section{1 \\ Global vs. Regional vs. Local}

\subsection{Global}

Colonialism and trade are where the global meets the local, as outlined by Sheng-Yu Huang, Te-Yen Liu, Cheng-Lun Tien and Amador IV Peleo in their paper on the role played by the former British Consulate at Takao (1864-1895) in forging trade links and international relations, especially with Southeast Asia. Although Takao in Taiwan was then deemed to be at "the world's end", its port did foster distinctive international links between Southern Taiwan and Southeast Asia. Small though the British operations in Takao might have been, the port served as a node in the nexus of commercial links spanning the Western Pacific Rim. Using the local customs reports of the era and the activities of the trading firm Jardine Matheson, the authors showed how the movement of goods and people between Southern Taiwan and Southeast Asia had been facilitated. Through their analyses on the trade links between Taiwan and Southeast Asia in the late Qing Dynasty era, they provide us with a different perspective on the current Taiwan government's New Southbound Policy (NSP), which, at its heart, melds the implementation of state policy with the conduct of international business.

Another more insidious instance of the international impinging upon the local can be seen in the deeds of international actors such as politicallymotivated terror groups like the Islamic State (IS) that seek to impose their radical beliefs and ways of life on the people of these other nations. Pak Nung Wong frankly delves into IS's global-localization strategy in Sri Lanka, Indonesia and the Philippines to demonstrate the extent to which the organization has successfully localized its efforts to bring chaos to the societies of 
those three countries. Contrary to claims by the US and its allies that the Islamic State's (IS) strongholds in Iraq and Syria have been entirely destroyed, the series of coordinated suicide bombings in Sri Lanka on Easter Sunday 2019, the terrorist attacks in Surabaya in Indonesia in May 2019, and the Battle of Marawi in the Philippines in 2017 indicate otherwise. They highlight that IS has become a globally networked organization by infiltrating the region through a global-localization strategy. By decentralizing its power away from its so-called caliphate in the Middle East, IS has connected with Muslim communities in the peripheral Global South to entice them to its cause. Wong goes over the IS-linked terror attacks in Sri Lanka, Indonesia and the Philippines in 2017-2019 to show the ways in which IS has achieved this. Using his analyses of the IS-affiliated attacks in the region as a springboard, he suggests what can be done locally in Sri Lanka to impede IS's further infiltration into society. His proposed solution is the establishment of a pluralistic and inclusive intelligence system through which the Sinhalese, Tamils and Muslims in Sri Lanka can come together and prevent further terrorist attacks. By making sure no one ethnic group is left out and actively included in intelligence work, he believes that the global-localization reach of terror network can be hampered.

While international cooperation and the bringing together of disparate groups is very good and well, there is the danger that one group or country might seek to extend its influence in a particular region or nation. However, ambitious leaders of self-proclaimed world powers who wish to extend their influence over other countries have to do so without appearing too forceful, lest they be accused of colonialism or militaristic, which are not very acceptable to the international community in the modern day. To sugarcoat their desire to shape other countries and render them more agreeable towards their methods, these world powers often start by launching initiatives within their own region, ostensibly for the improvement of trade and bilateral ties. But in the case of China's Belt and Road Initiative (BRI) that has been making significant inroads in Southeast Asia, it is clear a political agenda is behind the generous loans for grand infrastructural projects in the region, for China is making the recipient countries of BRI investments beholden to her for economic favors. In return, these countries are in danger of losing their political autonomy by falling into overdependence on China. Malaysia is no exception, as Emile Kok-Kheng Yeoh points out in his article on the enigmatic Sino-Malaysian relationship following the 2018 general election. While China certainly interfered in Malaysia's politics by supporting the continuation of Najib Razak's kleptocratic regime, warning off opposition leaders from questioning the trajectory of China-Malaysia relations and putting Malaysia in its debt for extravagant 
infrastructural projects in the run-up to the May 2019 election, it could not have expected that a new strongly anti-graft New Alliance of Hope coalition government would win. Neither did it expect the new coalition government to cancel several China-funded projects like the East Coast Rail Link (ECRL) so as to reduce the country's indebtedness to China and prevent Malaysia from becoming a pawn in China's ambitious regional agenda of advancement at the expense of her own national goals. But the new government did do these things immediately upon coming to power, deeming the previous administration's China deals as dubious and unequal because of the vast sums of money involved and because they were linked to the 1MDB scandal involving Najib and his cronies. China-Malaysia relations soured for a spell after that until the new government renegotiated the ECRL with a China at a much lower cost in early 2019 and brought back other shelved China-linked infrastructural projects to the negotiating table for possible re-launching on more "equal" terms. Relations between China and Malaysia also seemingly improved when New Malaysia's Prime Minister Mahathir Mohamad went to Beijing to announce his full support for the BRI at the 2nd Belt and Road Forum for International Cooperation (BRF) in late April 2019. Despite this mending of ties with China, the Sino-Malaysian relationship is still reconfiguring itself both in terms of international geopolitics and domestic political economy.

\section{$1.2 \quad$ Regional}

Political power play is not always all gloom and doom when the global impacts the regional, particularly if the issue at hand is climate change that affects the survival of the human race and planet earth. Southeast Asia as a region is committed to reducing carbon emissions and is consciously seeking to be more sustainable in its habits. When a local city government takes on the global issue of climate change, it is engaging actively in international affairs. This is a noble and timely modus operandi, as cities need to represent the current reality of the multi-centric world and the unavoidability of international issues that affect all of humanity. Baiq Wardani and Vinsensio Dugis explore this notion in their study on Surabaya's role in shaping environmental diplomacy and the ways in which the city is an example to the region in this respect. They stress that diplomacy is no longer the reserve of the political elites, as people at the grassroots-who fret over the same issues as national governments in regard to pollution and health concerns-need to have their interests taken into consideration. As the impact of environmental issues is far-reaching, cities ought to do what they can to mitigate (and if possible) reverse the negative effects for the good their people. The Indonesian city of Surabaya has achieved this to some degree of success, as it has managed to balance its rapid 
development with an active greening of its environs. Surabaya's mayor Risma is largely responsible for this as she has brought her city to the center of the diplomatic stage by making it down-to-earth and people-oriented, especially in environment-related issues. Her climate diplomacy has brought about energy conservation, effective waste management, attainment of the some of the sustainable development goals (SDGs), and the lowering of the city's average temperature by 2 degrees Celsius to 34 degrees Celsius. Wardhani and Dugis detail how Risma achieved this through multilateral engagements with companies, NGOs and civil society; bilateral partnerships such collaborative endeavors with sister cities; and local community involvement by encouraging recycling. Hence, Surabaya's success in environmental diplomacy showcases how it is possible for the local to "go international" by actively engaging with pertinent global issues and therefore becoming a model for the region vis-à-vis international social issues that affect each and every one of us

\subsection{Local}

Democracy may seem like an international institution to many of us, as we see voting, freedom of speech and political reform as part of our inalienable human rights. Within countries, however, democracy is a global right writ small as the way in which it is practised and exercised differs across the world's many nations. In Southeast Asia, ostensibly democratic countries do not always act democratically, possibly due to the preponderance of one-party states and strongman rule. Even so, it is generally accepted within the region that basic democratic rights ought to be used responsibly and not used to hurt others mentally, physically, economically, emotionally, socially or politically. What happens when political civil society groups and political parties within a democratic country exploits these internationally recognized rights and use them to incite suspicion and hatred against minorities? What happens when these rights are exploited by the democratic country's majority ethno-religious leadership to instill fear among the minorities? What happens when this democratic country has to call upon its local minority agencies to mitigate the effects of the resultant fallout? Broto Wardoyo considers these factors in his essay on Christian minorities and their response to the rise of Islamic politics in Indonesia in the post-Ahok period. By delving into the ways in which the criticisms and discrimination leveled at Ahok's alleged blaspheming of the Quran has shifted the attitudes of the preachers of the Javanese Christian Church or Gereja Kristen Jawa (GKJ) towards identity politics, he examines how GKJ preachers have become more melek politik or politically aware through their sermons in the wake of the Ahok case. GKJ is also aware that it has to do its part for its distressed congregations amidst the rise of Islamic 
politics in Indonesia, for all its official apoliticism. It has accordingly sought to mitigate the issue locally through political education for members of the Church and for politicians coming from within the ranks of the GKJ so as to not to stir up overt dissent that might potentially provoke international intervention in Indonesian political affairs. Through political education and sermons, GKJ leaders have managed to keep their congregations calm and tempered any overt reaction to Islamic politics, and in so doing, maintain some form of tenuous peace in Indonesian society.

As countries are sovereign entities, democratically elected governments in Southeast Asia, like their counterparts in other parts of the world, possess the right to tweak their style of governance to local customs and mores. On the one hand, this respects local traditions and beliefs, for most Southeast Asian nations are melting pots of various peoples and cultures. On the other, that which had initially been adjusted for local conditions could come to result in governments, especially those in power for an extended period of time, to becoming intransigent to change. They might be reluctant to adopt new modes of doing things because they fear the erosion of their culture and ways. They might be unwilling to try something new because they fear failure or they fear they might be ridiculed. Or, as in the case of the mass media in Malaysia, they are loath to adopt reforms issued by the Pakatan Harapan government to render them less biased and more transparent because the owners and editors of media networks continue to support the pro-Barisan Nasional narratives they helped shape for the past 60 years. This is emphatically argued in Gayathry Venkiteswaran's discussion on media reforms in Malaysia. Even though Malaysia's media needs shaking up after decades being under Barisan Nasional control and influence, the conservative nature of mainstream media in the country ensures that there are limited results vis-à-vis initiatives related to media work and laws. This is an especially frustrating state of affairs for workers in the media, who were looking forward to the freeing up the laws and rules on censorship and access to information, as promised by the Pakatan Harapan government when it came to power after the May 2018 general election. Venkiteswaran outlines how this frustration is additionally compounded through the half-cocked implementation of media reforms in Malaysia. She details how the realities of structural and political barriers as well as the power of the conservatively minded media owners and editors have only resulted in hurdles and U-turns at best when attempts were made at media-related reforms and the outright continuity of policies at worst. While it is acknowledged that the standing of the local mass media in the country has to be improved, the resistance of the major mainstream media players and bureaucratic hurdles are stronger than media workers' and the public's desire for reforms. Given this 
reality, it seems that for the foreseeable future, Malaysia's news media is unlikely to be up-to-date with international standards and unlikely to regain public confidence after years of declining trust. The only way around this is for Malaysia's media community to come together reclaim and defend its rights. Whether the mainstream media players are willing to adopt a more forward-looking and farsighted vision is unknown at present. But it is hoped that with enough pressure from the Malaysian media community, the mainstream media players, owners and editors can be made to change so that the country's mass media can be as unbiased and transparent as its international counterparts.

\section{2}

\section{Conclusion}

Inasmuch as local areas within countries have their own unique characteristics, regional delineations pertain to a specific geographic region with shared histories and similar socio-political systems, and global matters concern the whole world, the differences between these three categories are not that great. Whether local, regional or global, all countries desire peace and prosperity for themselves, their neighbors and their political-economic partners. Their reasons for wanting these things may be selfish, but these desires are universal nonetheless. Furthermore, people in all countries have the same basic needs, wants, wishes and problems. We all need water, food and shelter to survive; we all want good health for ourselves and our loved ones; we all want to live in peace with our fellowmen; we want to live a world that is free from strife; we all worry about bills and job security; we are all muddling along and do what we must to get by in life. However, as no man is an island, we should also remember that we are all capable of understanding one another as long as we do not become blinded by concerns for ourselves. Countries, be they in the Asia Pacific or otherwise, are no different, as they are the human condition writ large. They too are just as capable of great things as they are terrible ones; they too are desirous of peace and living harmoniously with other nations; they too are capable of understanding nations different from theirs if they focus on that which they have in common; they too can exist as good neighbors without compromising on caring for their own citizens; they too can exist as international partners and friends to the rest of the world without losing their own identities. The Asia Pacific cultural, historical, political, ecological and socioeconomic instances in this compilation have shown us exactly that. As evinced in this volume, countries and their governing systems, like the peoples all over the world, are interconnected. That which affects one country will affect its 
neighbors and the world; and that which impacts the world will trickle down and affect all countries, no matter how small.

*All papers were presented at the Wenzao International Conference on Southeast Asian Studies, held at Wenzao Ursuline University of Languages, Kaohsiung, Taiwan, 17-19, October, 2019. 